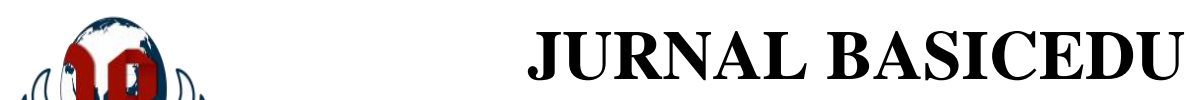

Volume 5 Nomor 4 Tahun 2021 Halaman 2311 - 2321

Research \& Learning in Elementary Education https://jbasic.org/index.php/basicedu

\title{
Pengembangan Media Pembelajaran Berbasis Game Interaktif untuk Meningkatkan Kemampuan Pemecahan Masalah Tematik di Sekolah Dasar
}

\author{
Andista Mutia Candra ${ }^{1 凶}$, Theresia Sri Rahayu ${ }^{2}$ \\ Universitas Kristen Satya Wacana, Indonesia ${ }^{1,2}$

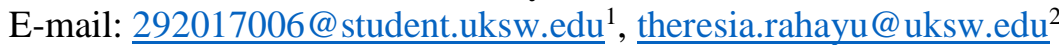

\begin{abstract}
Abstrak
Media pembelajaran memiliki peran yang sangat penting dalam proses pembelajaran. Tujuan dari penelitian ini yaitu untuk mengetahui tingkat validitas, tingkat kepraktisan dan tingkat efektifitas Media Pembelajaran Berbasis Game Interatif untuk Meningkatkan Kemampuan Pemecahan Masalah Tematik pada Materi Operasi Hitung Bilangan Cacah Kelas 2 SD. Jenis penelitian ini adalah pengembangan atau Research and Development (R\&D) yang telah dikembangkan oleh (Sukmadinata, 2016:164). Penelitian ini dilakukan menggunakan model pengembangan ADDIE yaitu Tahap Analisis (Analysis), Tahap Perancangan (Design), Tahap Pengembangan (Development), Implementasi (Implementation), Evaluasi (Evaluation). Data hasil uji validasi ahli diperoleh sebagai berikut: (1) persentase yang diperoleh dari uji validasi ahli materi sebesar $75 \%$ dengan kategori baik, sedangkan uji ahli media didapatkan skor sebesar $77 \%$ dengan kategori sangat baik. Berdasarkan data yang diperoleh dari uji validitas ahli materi dan ahli media, maka dapat disimpulkan bahwa Media Pembelajaran Berbasis Game Interatif untuk Meningkatkan Kemampuan Pemecahan Masalah Tematik pada Materi Operasi Hitung Bilangan Cacah Kelas 2 SD telah layak digunakan.
\end{abstract}

Kata Kunci: media pembelajaran, game, kemampuan pemecahan masalah.

\section{Abstract}

Learning media has a very important role in the learning process. The purpose of this research is to develop Interactive Game-Based Learning Media to Improve Thematic Problem-Solving Ability of Operational Material Counting Whole Numbers in Grade 2 Elementary School and aims to determine the level of validity of material experts and Interactive Game-Based Learning Media experts to Improve Thematic Problem-Solving Skills on Materials. Operation Counting Whole Numbers Class 2 SD. This type of research is Research and Development $(R \& D)$ which has been developed by (Sukmadinata, 2016:164). This research was conducted using the ADDIE development model, namely the Analysis Phase, Design Phase, Development Phase, Implementation, and Evaluation. The data from the expert validation test results were obtained as follows: (1) the percentage obtained from the material expert validation test was $75 \%$ in the very good category, while the media expert test obtained a score of 77\% in the very good category. Based on the data obtained from the validity test of material experts and media experts, it can be concluded that Interactive Game-Based Learning Media to Improve Thematic Problem Solving Ability in Operational Material Counting Whole Numbers for Grade 2 Elementary School has been feasible to use.

Keywords: learning media, games, problem solving skills.

Copyright (c) 2021 Andista Mutia Candra, Theresia Sri Rahayu

$\triangle$ Corresponding author :

Email : 292017006@student.uksw.edu

DOI : https://doi.org/10.31004/basicedu.v5i4.1212

ISSN 2580-3735 (Media Cetak)

ISSN 2580-1147 (Media Online)

Jurnal Basicedu Vol 5 No 4 Tahun 2021 p-ISSN 2580-3735 e-ISSN 2580-1147 
2312 Pengembangan Media Pembelajaran Berbasis Game Interaktif untuk Meningkatkan Kemampuan Pemecahan Masalah Tematik di Sekolah Dasar - Andista Mutia Candra, Theresia Sri Rahayu DOI: https://doi.org/10.31004/basicedu.v5i4.1212

\section{PENDAHULUAN}

Pendidikan merupakan hal yang tak bisa lepas dari kehidupan manusia. Tanpa adanya pendidikan maka generasi akan hancur dan terjadi kemerosotan kehidupan. Sekolah merupakan suatu tempat untuk menempuh pendidikan yang merupakan lembaga dengan tujuan pendidikan. Dalam dunia pendidikan, sekolah berperan dalam menyelenggarakan proses belajar mengajar. Pihak sekolah senantiasa membimbing, membina,dan mengembangkan potensi pada anak - anak. Pendidikan sekolah dasar berpengaruh besar dalam kehidupan jangka panjang manusia di masa mendatang. Pendidikan merupakan investasi jangka panjang bagi seseorang. Proses pendidikan membantu peserta didik berkembang dengan optimal dengan cara mengasah potensi dan bakatnya. Pendidikan merupakan upaya seseorang dalam mengembangkan dirinya secara maksimal dengan bantuan lembaga sekolah.

Pendidikan bertujuan agar peserta didik siap menghadapi segala kondisi dimasa mendatang dengan berbekal pengetahuan, keterampilan dan sikap yang baik. Pada waktu sekarang ini sejak tahun 2020 dunia telah diguncang pandemi yang bernama Covid 19. Tidak dipungkiri bahwa Covid 19 telah menghambat berbagai sektor mulai dari pemerintahan sampai pendidikan. Dampak pandemi ini mengharuskan semua orang untuk menjalankan PSBB dan berhati - hati dalam kehidupan sehari - hari mengingat Covid 19 sangat mudah menular dan banyak menimbulkan korban jiwa. Sehingga menteri pendidikan Indonesia memutuskan bahwa peserta didik harus belajar di rumah. Imbas pandemi ini dalam bidang pendidikan yaitu adanya cara mengajar baru yang dinamakan sistem Daring. Sistem daring sendiri tak lepas dari media pembelajaran seperti video pembelajaran terkait, aplikasi zoom atau google meet, atau media online lain yang dapat digunakan dalam proses pembelajaran. Melalui hasil pengamatan sistem daring ini membuat orang tua peserta didik kewalahan dan peserta didik pun kurang mengerti pembelajaran yang diajarakan. Media digunakan sebagai salah satu komponen strategi pembelajaran, berupa wadah dari pesan materi pembelajaran yang ingin disampaikan kepada penerima pesan, tujuannya yaitu terjadinya proses belajar (Al-Tabany, 2011). Dengan adanya perubahan dalam sistem belajar membuat peserta didik harus beradaptasi dengan kondisi yang tidak memungkinkan untuk bertatap muka, pembelajaran yang sulit mereka pahami ketika di rumah salah satunya adalah matematika materi operasi hitung bilangan cacah perkalian dan pembagian. Salah satu cara yang dapat dilakukan untuk mengatasi masalah tersebut yaitu dengan menggunakan game interaktif. Menurut (Costikyan, 2013), game adalah sebuah karya seni di mana peserta disebut pemain, membuat keputusan untuk mengelola sumber daya yang dimilikinya melalui benda di dalam game demi mencapai tujuan. Interaktif merupakan interaksi dua arah atau lebih antara pengguna media dengan media itu sendiri seperti audio, video, grafik, teks, animasi (Maryani, 2014). Sejalan dengan pendapat seorang ahli bernama (Milman, 2015) mengungkapkan bahwa menggunakan teknologi digital dapat memudahkan mahasiswa dan dosen dalam melaksanakan proses belajar mengajar yang terputus oleh jarak. Media pembelajaran lebih memungkinkan penyerapan materi yang disampaikan oleh guru untuk peserta didik lebih mudah tersampaikan dan mudah diterima secara baik dan maksimal oleh peserta didik. Maka dari itu salah satu inovasi dalam dunia pendidikan yang memungkinkan jika digunakan melalui sistem daring yaitu menggunakan game interaktif. Game interaktif dirancang untuk menarik minat peserta didik agar tidak bosan ketika belajar di rumah. Tidak dapat dipungkiri jika peserta didik menjadi kurang paham dengan materi yang diajarkan ketika berada di rumah. Oleh karena itu inovasi dalam pembelajaran perlu dilakukan. Melalui game interaktif offline yang dapat diunduh di smartphone mereka memungkinkan peserta didik untuk belajar sekaligus bermain. Game interaktif dikembangkan oleh peneliti merupakan media pembelajaran yang digunakan untuk meningkatkan kemampuan pemecahan masalah. (Wahyudi \& Anugraheni, 2017) menyatakan bahwa pemecahan masalah adalah usaha untuk menemukan solusi dari suatu masalah yang tidak rutin sehingga masalah tersebut dapat diselesaikan tanpa adanya kesulitan lagi. Hal ini sejalan dengan (Saraswati, 2018) yang mengemukakan bahwa kemampuan pemecahan masalah bukan merupakan hal yang asing karena dalam 
kehidupan selalu melakukan kegiatan yang berkaitan dengan proses pemecahan masalah dari hal yang sederhana sampai kompleks.

Dalam game interaktif bernama BUTEMA, pertama siswa akan diperlihatkan layar utama berupa ikon ikon yang mana berisi kompetensi dasar dan indikator, materi, informasi bagaimana cara bermain game BUTEMA. Peserta didik dapat bebas memainkan game perkalian atau pembagian terlebih dahulu. Terdapat 10 level dalam game ini, siswa dapat melanjutkan ke level selanjutnya jika siswa telah berhasil memecahkan masalah pada level sebelumnya. Media ini dibuat menggunakan aplikasi Adobe Flash. Dalam membuat game ini penulis lebih menekankan pada konsep perkalian dan pembagian bilangan cacah dalam soal cerita, selain itu penulis juga menekankan pada pemecahan masalah yang dipadukan dengan keaktifan siswa. Media ini didukung dengan tampilan yang menarik dan suara - suara yang diharapkan dapat menarik minat belajar siswa dan tentunya memudahkan siswa dalam belajar matematika terutama operasi hitung bilangan cacah perkalian pembagian dan siswa diharapkan memiliki ketertarikan dalam belajar walaupun dari rumah. Game ini juga bersifat offline sehingga hemat dan menimbulkan suasana belajar baru yang asik dan menyenangkan.

Matematika merupakan salah satu mata pelajaran yang ada di sekolah dasar. (Suhendri, 2011:32) mengungkapkan bahwa ilmu yang mempelajari tentang bangun, bilangan logika, dan hubungan antar konsep adalah pengertian dari matematika. Matematika dalam pembelajrannya biasanya menggunakan lambang atau simbol dalam menyelesaikan permasalahan dalam kehidupan sehari-hari. Seorang ahli matematika bernama James yang dikutip oleh (Ismunamto, 2011:6) mengungkapkan bahwa ilmu tentang logika mengenai konsep, susunan, besaran, dan bentuk yang saling berhubungan satu dengan yang lainnya merupakan hakikat matematatika. Maka dari itu dapat disimpulkan bahwa matematika merupakan mata pelajaran yang dipelajari dengan logika meliputi bilangan, bentuk bangun, hubungan antar konsep yang saling terhubung untuk menyelesaikan masalah yang ada. Melalui wawancara dan angket yang diberikan kepada guru kelas 2 SD N Sidorejo Lor 01 Salatiga mengungkapkan bahwa menurunnya tingkat pemahaman siswa saat ini berkaitan dengan perubahan pola belajar, yang semula bertatap muka menjadi pembelajaran model daring. Siswa sering kali mengalami kesulitan dalam memahami kalimat matematika tentang operasi hitung bilangan cacah. Maka dari itu peneliti memilih media pembelajaran berbasis game interaktif tentang operasi hitung perkalian dan pembagian pada bilangan cacah terutama pada pemecahan masalah soal cerita. Menurut (Clara et al., 2018) dengan judul "Pengembangan Game Interaktif pada Pembelajaran Tematik di Sekolah Dasar". Media yang dikembangkan berupa game yang berisi materi pelajaran bagi siswa. Media yang dibuat dirasa kurang sesuai dengan perkembangan siswa karena terlalu banyak tulisan sehingga siswa kurang mengerti. Penelitian yang dilakukan (Indrawati \& Suardiman, 2013) dengan judul Pengembangan Media Travel Game Untuk Pembelajaran Perkalian dan Pembagian Bilangan Pecahan Matematika SD Kelas V didapatkan hasil $\mathrm{t}$ hitung = -9,764 sehingga dapat dikatakan bahwa media travel game layak digunakan pada materi perkalian dan pembagian bilangan pecahan kelas V SD. Selain itu (Ratih, 2017) dengan judul "Penggunaan Multimedia Interaktif Bermuatan Game Edukasi untuk Meningkatkan Aktivitas dan Hasil Belajar Siswa Sekolah Dasar". Media yang digunakan merupakan game edukasi tentang rangka manusia. Media ini dibuat agar siswa menjadi aktif dalam pembelajaran IPA di SD, akan tetapi dalam penerapannya siswa hanya diam dan memainkan game. Hal ini akan lebih baik lagi jika siswa dapat bermain secara kelompok agar ada interaksi antar siswa. Penelitian selanjutnya (Paseleng \& Arfiyani, 2015) dengan judul "Media Pembelajaran Berbasis Multimedia Interaktif pada Mata Pelajaran Matematika di Sekolah Dasar". Media ini dibuat agar siswa menjadi aktif saat pembelajaran berlangsung, akan tetapi dalam penerapannya siswa hanya diam memainkan game tanpa adanya interaksi dengan teman sekelasnya. Hal ini dirasa kurang dalam membentuk siswa menjadi aktif. Penelitian relevan yang selanjutnya dilakukan oleh (Atmoko et al., 2017) bahwa "Pengembangan Media Utama (Ular Tangga Matematika) dalam Pemecahan Masalah Matematika Materi Luas Keliling Bangun Datar Kelas III SD/MI" berdasar hasil penilaian akhir dari ahli media diperoleh skor sebesar $95 \%$ termasuk kategori sangat baik dan hasil penilaian akhirdari ahli materi diperoleh skor sebesar $90 \%$ termasuk kategori sangat baik. Hasil tes 
evaluasi siswa rata-rata memperoleh skor sebesar 88,84. Hasil analisis tangggapan siswa terhadap media memperoleh skor sebesar 94,4\% dan pada angket keberterimaan media oleh guru memperoleh skor sebesar 90\%. Hal ini menunjukan bahwa media UTAMA / Ular Tangga Matematika dinyatakan valid dan layak digunakan dalam pembelajaran di sekolah dasar. Kemudian penelitian yang dilakukan oleh (Wardani \& Setyadi, 2020) bahwa "Pengembangan Media Pembelajaran Matematika Berbasis Macromedia Flash Materi Luas Dan Keliling Untuk Meningkatkan Motivasi Belajar Siswa" berdasar hasil validasi media terlihat bahwa dalam aspek tampilan terlihat sangat baik dengan perolehan skor 4. Dalam uji validasi media perlu melakukan revisi sebanyak dua kali meliputi musik, home page kalimat dan perubahan animasi. Setelah melalui uji coba, diperoleh hasil yang valid. Aspek tampilan cenderung sangat baik dan aspek fungsi memperoleh skor 3,45.

Penelitian ini mengembangkan Media Pembelajaran Berbasis Game Interatif untuk Meningkatkan Kemampuan Pemecahan Masalah Tematik pada Materi Operasi Hitung Bilangan Cacah Kelas 2 SD. Penggunaan game interaktif dapat dimainkan oleh siswa kelas 2 dan berguna untuk membantu siswa kelas 2 dalam memahami materi operasi hitung bilangan cacah. Sehingga dengan adanya game interaktif ini dapat membuat siswa lebih mudah memahi materi operasi hitung bilangan cacah dimasa pandemi seperti sekarang ini. Game interaktif ini juga memberikan pengalaman baru bagi siswa kelas 2, karena di masa pandemi yang dirasa kegiatan pembelajaran yang semakin hari semakin membosankan. Namun dengan adanya game interaktif yang berisi materi operasi hitung bilangan cacah dapat diakses di smartphone dan laptop membuat siswa dapat belajar dan bermain game interaktif dimana saja dan kapan saja dengan bimbingan atau pengawasan orangtua sehingga dapat meningkatkan kemampuan pemecahan masalah tematik pada materi operasi hitung bilangan cacah kelas 2 SD. Selain itu, media pembelajaran berbasis game interaktif ini juga dapat dijadikan sebuah referensi dan sumber belajar untuk guru dalam menggunakan media pembelajaran khususnya materi operasi hitung bilangan cacah. Penelitian ini terdapat keunikan yakni dilakukan pada masa pandemi covid-19 yang mengharuskan semua kegiatan pembelajaran dilaksanakan secara daring sehingga penelitian dan pengembangan media pembelajaran berbasis game interaktif untuk meningkakan kemampuan pemecahan masalah tematik pada materi operasi hitung bilangan cacah kelas 2 SD hanya dapat dilaksanakan sampai uji validitas dari ahli materi dan ahli media saja. Sehingga yang dapat diketahui dari penelitian ini hanya tingkat validitas dari game interaktif saja. Tingkat kepraktisan dan tingkat keefektifan tidak dapat diketahui karena game interaktif ini tidak diujicobakan kepada siswa kelas 2 SD. Penelitian ini bertujuan untuk mengetahui tingkat validitas, tingkat kepraktisan, dan tingkat keefektifan Media Pembelajaran Berbasis Game Interatif untuk Meningkatkan Kemampuan Pemecahan Masalah Tematik pada Materi Operasi Hitung Bilangan Cacah Kelas 2 SD.

\section{METODE}

Penelitian dan Pengembangan Media Pembelajaran Berbasis Game Interatif untuk Meningkatkan Kemampuan Pemecahan Masalah Tematik pada Materi Operasi Hitung Bilangan Cacah Kelas 2 SD telah dilaksanakan menggunakan metode R\&D yang telah dikembangkan oleh (Sukmadinata, 2016:164) Penelitian ini dilakukan menggunakan model pengembangan ADDIE yaitu Tahap Analisis (Analysis), Tahap Perancangan (Design), Tahap Pengembangan (Development), Implementasi (Implementation), Evaluasi (Evaluation), Atwi (Suparman, 2012). Namun penelitian pengembangan ini hanya dapat dilaksanakan sampai tahap uji validitas ahli materi dan ahli media saja. Hal ini disebabkan karena adanya virus covid-19 yang masih ada di Indonesia dan jumlah korban covid-19 yang semakin meningkat, sehingga mengharuskan kegiatan pembelajaran di Sekolah Dasar dilaksanakan secara daring. Penelitian ini bertujuan untuk mengetahui tingkat validitas, tingkat kepraktisan, dan tingkat keefektifan Media Pembelajaran Berbasis Game Interatif untuk Meningkatkan Kemampuan Pemecahan Masalah Tematik pada Materi Operasi Hitung Bilangan Cacah Kelas 2 SD. Validasi berguna untuk menilai media berupa media pembelajaran berbasis game interaktif yang telah dikembangkan. Data tersebut diperoleh dari ahli media dan ahli materi. Kemudian dianalisis menggunakan teknik deskriptif 
presentase dan kategori yang berguna untuk menggambarkan kelayakan uji coba produk media pembelajaran berupa media pembelajaran berbasis game interaktif. Skor hasil validasi materi dan validasi media dipresentasekan menggunakan rumus sebagai berikut :

Keterangan:

$$
\mathrm{AP}=\frac{\text { Skor Aktual }}{\text { Skor ideal }} \times 100 \%
$$

AP

: Angka Presentase

Skor Aktual : Skor yang diberikan oleh validator ahli

Skor ideal : Skor maksimal hasil kali jumlah item dengan skor maksimal dari masing - masing item

Angka presentasi yang diperoleh selanjutnya dikelompokkan kedalam kriteria penilaian tabel 1.

Tabel 1

Kategori Uji Validasi Ahli

\begin{tabular}{cc}
\hline Interval & Kategori \\
\hline $0-25 \%$ & Sangat Tidak Baik (STB) \\
\hline $26 \%-50 \%$ & Tidak Baik (TB) \\
\hline $51 \%-75 \%$ & Baik (B) \\
\hline $76 \%-100 \%$ & Sangat Baik (SB) \\
\hline
\end{tabular}

Hasil dari uji validasi materi dan validasi media dari media pembelajaran berbasis game interaktif dapat dikatakan layak untuk diujicobakan jika presentase minimal mencapai kategori tinggi yaitu $\geq 61 \%$ (Mawardi, 2014:113). Namun karena adanya covid-19 yang mengharuskan pembelajaran dilaksanakan secara daring sehingga produk tidak diujicobakan ke siswa kelas 2 Sekolah Dasar.

\section{HASIL DAN PEMBAHASAN}

Hasil studi pendahuluan dilaksanakan untuk mengembangkan media pembelajaran berbasis game interatif untuk meningkatkan kemampuan pemecahan masalah tematik pada materi operasi hitung bilangan cacahkelas 2 SD. Dalam studi pendahuluan dilakukan melalui dua tahap yaitu studi pustaka dan studi lapangan. Dalam hal ini studi pustaka dilakukan melalui buku-buku terkait dan jurnal penelitian yang relevan. Studi pustaka berfungsi mengumpulkan data - data yang terkait dengan penelitian Pengembangan Media Pembelajaran Berbasis Game Interatif untuk Meningkatkan Kemampuan Pemecahan Masalah Tematik pada Materi Operasi Hitung Bilangan Cacah Kelas 2 SD. Kemudian dalam studi lapangan, peneliti telah mewawancarai guru kelas 2 SD Negeri Sidorejo Lor 01 Salatiga dan didapatkan hasil yaitu peserta didik belum pernah menggunakan game interaktif sebelumnya dan pembelajaran dilakukan hanya dengan penjelasan oleh guru melalui papan tulis dan buku paket. Kemudian dalam pemberian tugas dikarenakan pembelajaran saat ini menggunakan daring siswa siswa menjadi sulit memahami kalimat matematika dalam soal cerita perkalian dan pembagian bilangan cacah.

Dalam hal ini, penelitian ini dimaksudkan untuk mengembnagkan Media Pembelajaran Berbasis Game Interatif untuk Meningkatkan Kemampuan Pemecahan Masalah Tematik pada Materi Operasi Hitung Bilangan Cacah Kelas 2 SD. Penelitian ini memanfaatkan smarthphone dan laptop / komputer sebagai sarana mengakses Media Pembelajaran Berbasis Game Interatif untuk Meningkatkan Kemampuan Pemecahan Masalah Tematik pada Materi Operasi Hitung Bilangan Cacah Kelas 2 SD. Pada saat kegiatan atau pembelajaran menggunakan media BUTEMA jika peserta didik berada di sekolah dapat menuju ke lab komputer yang tersedia di sekolah. Kemudian jika peserta didik sedang di rumah peserta didik dapat meminjam smarthphone orang tua untuk mengakses game BUTEMA. Pada saat kegiatan pembelajaran menggunakan media BUTEMA berlangsung diharapkan peserta didik menjadi tertarik dan antusias dalam belajar, terlebih pada perkalian dan pembagian bilangan cacah. Diharapkan ketika pembelajaran berlangsung, orang tua atau guru dapat selalu mengawasi aktifitas peserta didik agar pembelajaran dapat berjalan kondusif. 
Pengembangan model ADDIE dalam Media Pembelajaran Berbasis Game Interatif untuk Meningkatkan Kemampuan Pemecahan Masalah Tematik pada Materi Operasi Hitung Bilangan Cacah Kelas 2 SD melalui beberapa tahap yaitu Tahap Analisis (Analysis), Tahap Perancangan (Design), Tahap Pengembangan (Development), Implementasi (Implementation), Evaluasi (Evaluation), menurut (Suparman, 2012). Pada tahap pertama yakni tahap analisis (Analysis), Analisis kinerja telah dilakukan untuk mengetahui dan mengklarifikasi masalah mendasar yang dihadapi dalam pembelajaran Tema 2 Bermain di Lingkunganku subtema 2 Bermain di Rumah Teman. Berdasarkan hasil wawancara dengan guru kelas 2 SD Negeri Sidorejo Lor 01 Salatiga masalah yang dihadapi dalam penelitian ini adalah belum adanya media pembelajaran yang mengaitkan materi dengan sebuah permainan yang menyenangkan untuk memecahkan masalah pada siswa, sehingga dibutuhkan solusi berupa media pembelajaran berbentuk game interaktif yang menyenangkan untuk menari minat siswa dalam belajar. Analisis kebutuhan merupakan tahapan untuk menentukan kompetensi yang perlu dipelajari siswa untuk meningkatkan kemampuan pemecahan masalah. Berdasarkan hasil analisis kurikulum di SD Negeri Sidorejo 01 Salatiga menggunakan kurikulum 2013. Berdasarkan kurikulum yang digunakan di SD Negeri Sidorejo Lor 01 Salatiga, peneliti memutuskan membuat media pembelajaran berupa game interaktif untuk membantu siswa dalam kegiatan pembelajaran Tema 2 Bermain di Lingkunganku Subtema 2 Bermain di Rumah Teman. Pembelajaran di kelas II SD Negeri Sidorejo Lor 01 Salatiga merupakan pembelajaran tematik terpadu, sehingga peneliti akan mengembangkan materi pada Tema 2 Bermain di Lingkunganku, subtema 2 Bermain di rumah teman menjadi sebuah media game interaktif. Pembuatan media game interaktif ini diharapkan dapat meningkatkan kemampuan pemecahan masalah siswa kelas 2 SD terutama materi perkalian dan pembagian dalam soal cerita bilangan cacah.

Pada tahap kedua yakni tahap perancangan (Design), Dalam tahap perancangan media BUTEMA peneliti melakukan langkah - langkah sebagai berikut : 1) Langkah pertama yakni menentukan judul dan tema media game interaktif yang akan disusun. Judul dan media yang ditentukan didasari oleh kompetensi dasar dan indikator - indikator, dan materi pembelajaran yang termuat dalam kurikulum. Tema media game interaktif ditentukan berdasarkan pada Tema 2 Bermain di Lingkunganku Subtema 2 Bermain di Rumah Teman yang sesuai buku siswa dan buku guru kurikulum 2013. Pada game BUTEMA peneliti menekankan penanaman konsep tentang perkalian dan pembagian dengan menggunakan benda - benda disekitar peserta didik yaitu buah - buahan. Selain itu nama BUTEMA sendiri merupakan sebuah singkatan dari buah matematika yang menunjukan bahwa game tersebut merupakan game matematika dengan aneka buah - buahan. Hal tersebut sesuai dengan buku paket Tema 2 Bermain di Lingkunganku Subtema 2 Bermain di Rumah Teman yang mana banyak menampilkan buah - buahan dalam soal cerita, sehingga materi dalam buku dan yang terdapat dalam game dapat sinkron di pikiran peserta didik. 2) Langkah kedua yakni menyiapkan buku-buku sumber dan referensi lainnya. Materi yang disajikan dalam game BUTEMA menggunakan sumber buku siswa dan buku guru kurikulum 2013 dengan Tema 2 Bermain di Lingkunganku Subtema 2 Bermain di Rumah Teman. Hal ini dilakukan karena game BUTEMA ini dibuat sebagai bahan latihan soal dan penguatan materi peserta didik. Jadi materi dan soal yang ada sesuai dengan buku guru dan siswa Tema 2 Bermain di Lingkunganku Subtema 2 Bermain di Rumah Teman. Selain menggunakan buku guru dan siswa peneliti juga memanfaatkan internet dan referensi lainnya seperti jurnal - jurnal ilmiah sebagai tambahan materi pelajaran. 3) Langkah ketiga yakni melakukan identifikasi terhadap kompetensi dasar, serta merancang bentuk kegiatan pembelajaran yang sesuai. Identifikasi terhadap kompetensi dasar dan indikator dilakukan dengan cara memilih kompetensi dasar berdasarkan kurikulum 2013 yang terdapat pada Tema 2 Bermain di Lingkunganku Subtema 2 Bermain di Rumah Teman yang akan disusun dalam bentuk media game interaktif BUTEMA. Kompetensi Dasar kelas II tema 2 Bermain di Lingkunganku, subtema 2 Bermain di Rumah Teman, pembelajaran ke 1. Melakukan identifikasi terhadap indikator pencapaian kompetensi, serta merancang bentuk kegiatan pembelajaran yang sesuai. Identifikasi terhadap indikator pencapaian kompetensi dilakukan dengan cara menentukan indikator pencapaian kompetensi pada Tema 2 Bermain di Lingkunganku Subtema 2 Bermain. Indikator kelas II tema 2 
2317 Pengembangan Media Pembelajaran Berbasis Game Interaktif untuk Meningkatkan Kemampuan Pemecahan Masalah Tematik di Sekolah Dasar - Andista Mutia Candra, Theresia Sri Rahayu DOI: https://doi.org/10.31004/basicedu.v5i4.1212

Bermain di Lingkunganku, subtema 2 Bermain di Rumah Teman, pembelajaran ke 1. Berikut ini Kompetensi Dasar dan Indikator pada Tema 2 Bermain di Lingkunganku Subtema 2 Bermain :

Tabel 2

Kompetensi Dasar dan Indikator

\begin{tabular}{llll}
\hline \multicolumn{1}{c}{ Kompetensi Dasar } & \multicolumn{1}{c}{ Indikator } \\
\hline 3.4 & $\begin{array}{l}\text { Menjelaskan perkalian dan pembagian yang } \\
\text { melibatkan bilangan cacah dengan hasil kali } \\
\text { sampai dengan 100 dalam kehidupan sehari - } \\
\text { hari serta mengaitkan perkalian dan pembagian. }\end{array}$ & $\begin{array}{l}\text { Memecahkan masalah berkaitan dengan } \\
\text { dua bilangan cacah yang hasil kalinya } \\
\text { diketahui. } \\
\text { Memecahkan masalah berkaitan dengan } \\
\text { dua bilangan cacah yang hasil } \\
\text { pembagiannya diketahui. }\end{array}$ \\
\hline $4.4 \quad \begin{array}{l}\text { Menyelesaikan masalah perkalian dan } \\
\text { pembagian yang melibatkan bilangan cacah } \\
\text { dengan hasil kali sampai dengan 100 dalam } \\
\text { kehidupan sehari-hari serta mengaitkan } \\
\text { perkalian dan pembagian. }\end{array}$ & 4.4 .1 & $\begin{array}{l}\text { Menentukan dua bilangan cacah yang } \\
\text { hasil kalinya diketahui melalui soal } \\
\text { cerita. } \\
\text { Menentukan dua bilangan cacah yang } \\
\text { hasil pembagiannya diketahui melalui } \\
\text { soal cerita. }\end{array}$ \\
\hline
\end{tabular}

5) Langkah kelima yakni merancang media game interaktif. Media game interaktif BUTEMA dirancang dalam bentuk media permainan yang dapat dimainkan di smartphone dan laptop/komputer. Sehingga ketika peserta didik tidak diperbolehkan membawa smartphone ke sekolah peserta didik dan guru dapat menggunakan lab. Komputer sekolah. Hal ini dirasa cukup memudahkan peserta didik dan guru dalam penggunaan game BUTEMA. Isi materi yang akan digunakan dalam media game interaktif BUTEMA sesuai dengan buku siswa kelas II Tema 2 Bermain di Lingkunganku Subtema 2 Bermain di Rumah Teman yaitu pembagian dan perkalian bilangan cacah. Dalam game BUTEMA peneliti lebih fokus pada pemecahan masalah matematika terutama soal cerita.

Pada tahap ketiga yakni tahap pengembangan (Development). Pada tahap ini, media game BUTEMA dikembangkan dengan melalui uji validasi ahli materi, ahli media dan revisi produk. Selanjutnya tahap keempat yakni tahap Implementasi (Implementation). Pada tahap ini, setelah media BUTEMA sudah disusun menjadi produk final yang kemudian dilakukan uji pakar seperti pakar media dan pakar materi. Validasi media pada Media Pembelajaran Berbasis Game Interatif untuk Meningkatkan Kemampuan Pemecahan Masalah Tematik pada Materi Operasi Hitung Bilangan Cacah Kelas 2 SD dilakukan oleh dosen Program Studi Guru Sekolah Dasar, Fakultas Keguruan dan Ilmu Pendidikan, Universitas Kristen Satya Wacana, yaitu Gamaliel Septian Airlanda, M.Pd. Validasi media dilakukan dengan memberikan rubrik instrumen uji validasi media yang terdapat 4 aspek uji validasi media yakni aspek tampilan, aspek interaksi, aspek kontrol dan aspek bentuk. Validasi ahli media dilakukan dengan memberikan rubrik penilaian uji validasi media sebanyak 19 indikator dengan 4 pilihan jawaban yaitu STB, TB, B, SB. Berikut ini data hasil validasi ahli media :

Tabel 3

Data Hasil Validasi Media

\begin{tabular}{rlcc}
\hline \multicolumn{1}{c}{ Aspek } & Skor Aktual & $\begin{array}{c}\text { Skor } \\
\text { Ideal }\end{array}$ \\
\hline 1. & Tampilan & 26 & 32 \\
\hline 2. & Interaksi & 8 & 12 \\
\hline 3. & Kontrol & 13 & 16 \\
\hline 4. & Bentuk & 12 & 16 \\
\hline Total skor & 59 & 76 \\
\hline
\end{tabular}


2318 Pengembangan Media Pembelajaran Berbasis Game Interaktif untuk Meningkatkan Kemampuan Pemecahan Masalah Tematik di Sekolah Dasar - Andista Mutia Candra, Theresia Sri Rahayu DOI: https://doi.org/10.31004/basicedu.v5i4.1212

$$
\begin{aligned}
& \mathrm{AP}=\frac{\text { Skor Aktual }}{\text { Skor ideal }} \times 100 \%= \\
& \mathrm{AP}=\frac{59}{76} \times 100 \%=77 \%
\end{aligned}
$$

Sedangkan validasi materi pada Media Pembelajaran Berbasis Game Interatif untuk Meningkatkan Kemampuan Pemecahan Masalah Tematik pada Materi Operasi Hitung Bilangan Cacah Kelas 2 SD dilakukan oleh dosen Program Studi Guru Sekolah Dasar, Fakultas Keguruan dan Ilmu Pendidikan, Universitas Kristen Satya Wacana, yaitu Yohana Setiawan, S.Pd.,M.Pd. Validasi materi dilakukan dengan memberikan rubrik instrumen uji validasi materi yang terdapat 3 aspek menurut (Akbar, 2013:39) yakni aspek relevansi, keakuratan, sistematika sajian. Validasi ahli materi dilakukan dengan memberikan rubrik penilaian uji validasi media sebanyak 8 indikator dengan 4 pilihan jawaban yaitu STB, TB, B, SB. Berikut ini data hasil validasi ahli materi:

Tabel 4

\section{Hasil Data Validasi Materi}

\begin{tabular}{clcc}
\hline & Aspek & $\begin{array}{c}\text { Skor } \\
\text { Aktual }\end{array}$ & Skor Ideal \\
\hline 1. & Relevansi & 10 & 12 \\
\hline 2. & Keakuratan & 6 & 8 \\
\hline 3. & $\begin{array}{l}\text { Sistematika } \\
\text { sajian }\end{array}$ & 8 & 12 \\
\hline & Total skor & 24 & 32 \\
\hline
\end{tabular}

$$
\begin{aligned}
& \mathrm{AP}=\frac{\text { Skor Aktual }}{\text { Skor ideal }} \times 100 \%= \\
& \mathrm{AP}=\frac{24}{32} \times 100 \%=75 \%
\end{aligned}
$$

Tahap terakhir yakni tahap Evaluasi (Evaluation). Dalam tahap evaluasi game BUTEMA pada awalnya memiliki banyak kekurangan seperti materi kurang lengkap, tulisan terlalu kecil, lagu kurang menarik untuk belajar dan lain-lain sehingga game BUTEMA telah melalui revisi sebanyak dua kali untuk memperbaiki kualitas game dalam Media Pembelajaran Berbasis Game Interatif untuk Meningkatkan Kemampuan Pemecahan Masalah Tematik pada Materi Operasi Hitung Bilangan Cacah Kelas 2 SD.

Spesifikasi produk media pembelajaran berupa Media Pembelajaran Berbasis Game Interatif untuk Meningkatkan Kemampuan Pemecahan Masalah Tematik pada Materi Operasi Hitung Bilangan Cacah Kelas 2 SD, sebagai berikut :

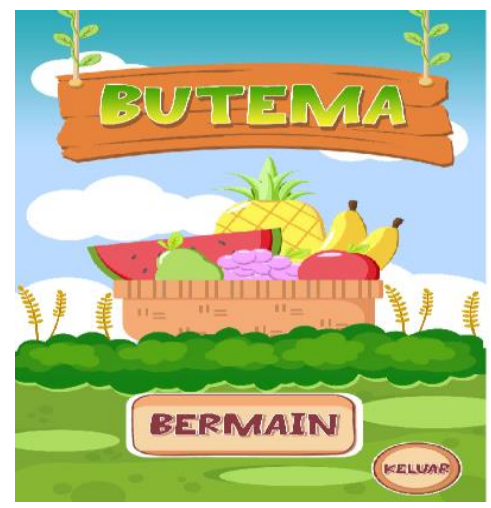

Gambar 1. Tampilan Menu Bar

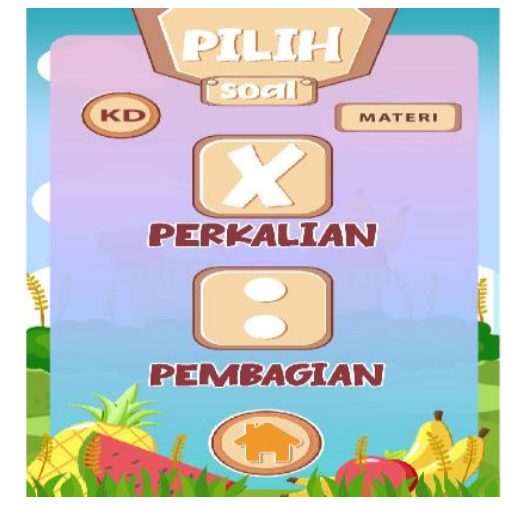

Gambar 2. Tampilan Menu Home 
2319 Pengembangan Media Pembelajaran Berbasis Game Interaktif untuk Meningkatkan Kemampuan Pemecahan Masalah Tematik di Sekolah Dasar - Andista Mutia Candra, Theresia Sri Rahayu DOI: https://doi.org/10.31004/basicedu.v5i4.1212

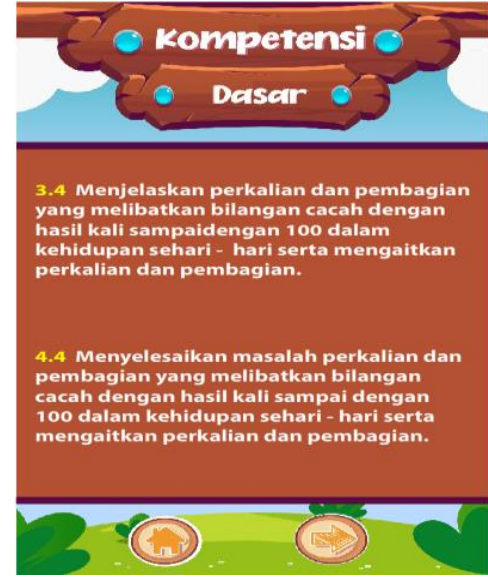

Gambar 3. Tampilan Kompetensi Dasar

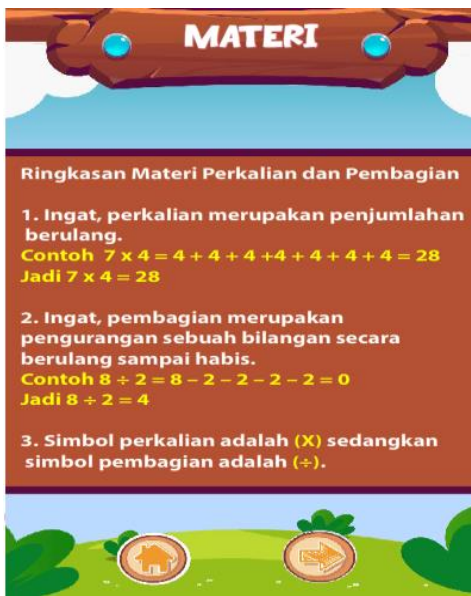

Gambar 5. Tampilan Materi

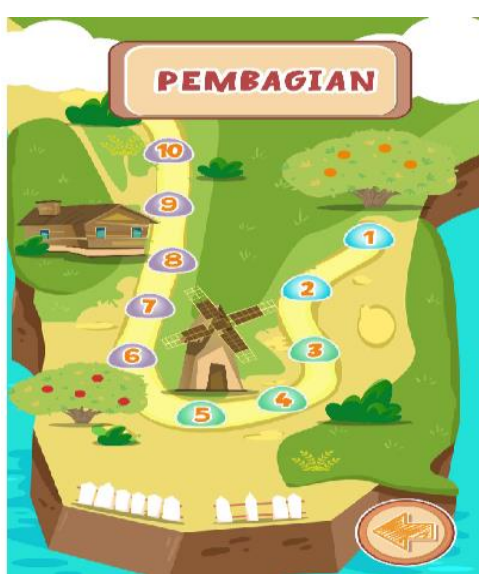

Gambar 7. Tampilan Pembagian

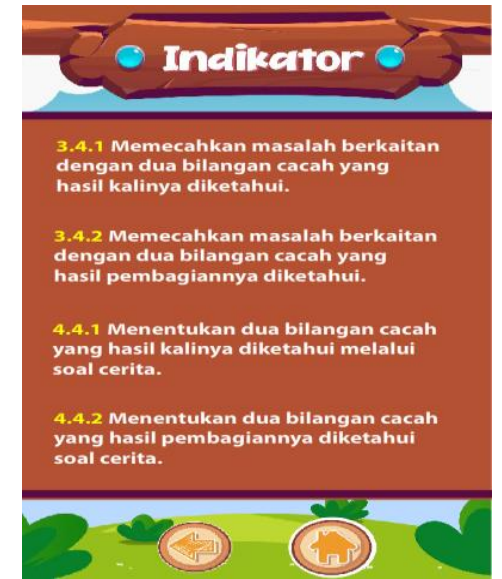

Gambar 4. Tampilan Indikator

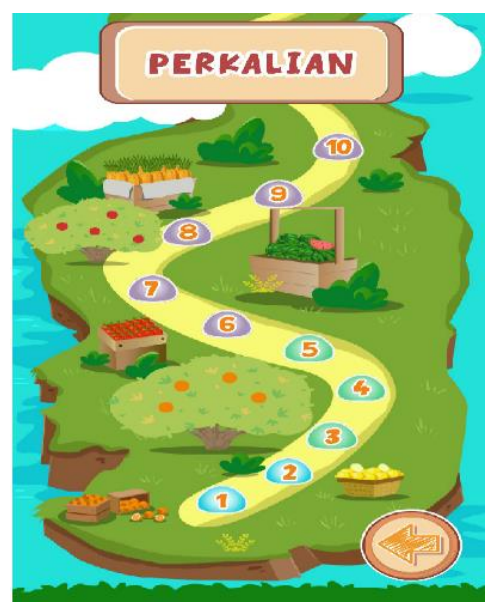

Gambar 6. Tampilan Perkalian

Penelitian ini mengembangkan Media Pembelajaran Berbasis Game Interatif untuk Meningkatkan Kemampuan Pemecahan Masalah Tematik pada Materi Operasi Hitung Bilangan Cacah Kelas 2 SD. Penggunaan game interaktif dapat dimainkan oleh siswa kelas 2 dan berguna untuk membantu siswa kelas 2 dalam memahami materi operasi hitung bilangan cacah. Sehingga dengan adanya game interaktif ini dapat membuat siswa lebih mudah memahi materi operasi hitung bilangan cacah dimasa pandemi seperti sekarang ini. Game interaktif ini juga memberikan pengalaman baru bagi siswa kelas 2, karena di masa pandemi yang dirasa kegiatan pembelajaran yang semakin hari semakin membosankan. Namun dengan adanya game interaktif yang berisi materi operasi hitung bilangan cacah dapat diakses di smartphone dan laptop membuat siswa dapat 
belajar dan bermain game interaktif dimana saja dan kapan saja dengan bimbingan atau pengawasan orangtua sehingga dapat meningkatkan kemampuan pemecahan masalah tematik pada materi operasi hitung bilangan cacah kelas 2 SD. Selain itu, media pembelajaran berbasis game interaktif ini juga dapat dijadikan sebuah referensi dan sumber belajar untuk guru dalam menggunakan media pembelajaran khususnya materi operasi hitung bilangan cacah.

Penelitian dan pengembangan Media Pembelajaran Berbasis Game Interatif untuk Meningkatkan Kemampuan Pemecahan Masalah Tematik pada Materi Operasi Hitung Bilangan Cacah Kelas 2 SD sesuai dengan penelitian yang dilakukan oleh (Fatimah, 2020) bahwa Pengembangan Media Katela untuk Operasi Hitung Perkalian Pada Siswa 2 Sekolah Dasar berdasar dari proses validasi ahli media diperoleh presentase sebesar 90\% dengan kategori sangat baik. Sedangkan validasi ahli materi memperoleh presentase sebesar 77\% dengan kategori baik. Kemudian validasi ahli video animasi memperoleh presentase $90 \%$ dengan kategori sangat baik. Berdasarkan hasil validasi dari ahli, maka dapat dikatakan media Katela untuk operasi hitung perkalian dinyatakan layak untuk digunakan dalam proses pembelajaran. Penelitian relevan selanjutnya dilakukan oleh (Windawati, 2021) bahwa Game Edukasi Berbasis Android untuk Meningkatkan Hasil Belajar Siswa Sekolah Dasar diperoleh hasil validasi dari ahli materi sebesar 73\% dengan kategori tinggi. Sedangkan hasil validasi dari ahli media sebesar 97\% dengan kategori sangat tinggi. Berdasarkan uji validasi dari ahli, maka dapat disimpulkan bahwa game edukasi berbasis android untuk meningkatkan hasil belajar tema 7 pada siswa kelas IV dapat dikatakan layak digunakan.

Media Pembelajaran Berbasis Game Interatif untuk Meningkatkan Kemampuan Pemecahan Masalah Tematik pada Materi Operasi Hitung Bilangan Cacah Kelas 2 SD memiliki keterbatasan yakni media hanya dapat digunakan pada materi operasi hitung bilangan cacah perkalian dan pembagian terutama soal cerita. Kemudian memerlukan pemahaman serta konsentrasi untuk menemukan konsep materi operasi hitung bilangan cacah perkalian dan pembagian. Selanjutnya memerlukan komunikasi yang baik antara guru dan siswa, agar pembelajaran berlangsung baik dan siswa juga mengerti materi yang diajarkan. Dalam menginstal game interaktif membutuhkan kuota data yang cukup besar.

\section{KESIMPULAN}

Penelitian ini dilakukan untuk menjawab rumusan masalah tentang kevalidan, kepraktisan dan keefektifan Media Pembelajaran Berbasis Game Interatif untuk Meningkatkan Kemampuan Pemecahan Masalah Tematik pada Materi Operasi Hitung Bilangan Cacah Kelas 2 SD. Pengembangan media pembelajaran berbasis game interaktif ini tidak dapat diuji cobakan kepada siswa kelas 2 Sekolah Dasar sehingga penelitian ini hanya dapat untuk mengetahui uji validitas oleh ahli materi dan ahli media saja, sedangkan uji praktis dan efektif tidak dilaksanakan sehingga hasilnya tidak diketahui. Hal ini terjadi karena masa pandemi covid-19 yang mengakibatkan kegiatan pembelajaran dilaksanakan secara daring. Sehingga penelitian ini hanya dapat dilakukan uji validitas dari ahli saja. Penelitian pengembangan ini telah mengembangkan Media Pembelajaran Berbasis Game Interatif untuk Meningkatkan Kemampuan Pemecahan Masalah Tematik pada Materi Operasi Hitung Bilangan Cacah Kelas 2 SD telah melalui uji validitas ahli materi dan media. Presentase yang didapat dalam tahap uji ahli materi dihasilkan skor $75 \%$ dengan kategori baik. Sedangkan uji ahli media dihasilkan presentase sebesar 77\% dengan kategori sangat baik. Maka dapat disimpulkan bahwa Media Pembelajaran Berbasis Game Interatif untuk Meningkatkan Kemampuan Pemecahan Masalah Tematik pada Materi Operasi Hitung Bilangan Cacah Kelas 2 SD telah layak digunakan.

\section{DAFTAR PUSTAKA}

Akbar. (2013). Instrumen perangkat pembelajaran. PT. Remaja Rosdakarya.

Al-Tabany, I. B. T. (2011). Desain Pengembangan Pembelajaran Tematik Bagi Anak Usia Dini TK/RA \&Anak Usia Kelas Awal SD/MI. Kencana. 
2321 Pengembangan Media Pembelajaran Berbasis Game Interaktif untuk Meningkatkan Kemampuan Pemecahan Masalah Tematik di Sekolah Dasar - Andista Mutia Candra, Theresia Sri Rahayu DOI: https://doi.org/10.31004/basicedu.v5i4.1212

Atmoko, S. W., Cahyadi, F., \& Listyarini, I. (2017). Pengembangan Media Utama (Ular Tangga Matematika) dalam Pemecahan Masalah Matematika Materi Luas Keliling Bangun Datar Kelas III SD/MI. Al Ibtida: Jurnal Pendidikan Guru MI, 4(1), 119. https://doi.org/10.24235/al.ibtida.snj.v4i1.1476

Clara, Y., Supriyati, Y., Situmorang, R., \& Jakarta, U. N. (2018). Pengembangan Game Interaktif Pada. $94-$ 98.

Costikyan, G. (2013). Uncertainty In Games. The MIT Press.

Fatimah, D. (2020). Pengembangan Media Katela untuk Operasi Hitung Perkalian Pada Siswa 2 Sekolah Dasar. Jurnal Penelitian Dan Pengembangan ..., 4, 526-532. https://ejournal.undiksha.ac.id/index.php/JJL/article/view/29741

Indrawati, D., \& Suardiman, S. P. (2013). Pengembangan Media Travel Game Untuk Pembelajaran Perkalian Dan Pembagian Bilangan Pecahan Matematika Sd Kelas V. Jurnal Prima Edukasia, 1(2), 135-146. https://doi.org/10.21831/jpe.v1i2.2631

Ismunamto, A. (2011). Ensiklopedia Matematika. Penerbit Khusus Buku - buku Ensiklopedia.

Maryani., D. (2014). Pembuatan Media Pembelajaran Interaktif Bangun Ruang Matematika. Jurnal Speed, 6, 2.

Mawardi. (2014). Model Desain Pembelajaran Kosep Dasar PKn Berbasis Belajar Mandiri Menggunakan Moodle. Widya Sari Press.

Milman, N. B. (2015). Education, Distance. In International Encyclopedia of the Social \& Behavioral Sciences: Second Edition. https://doi.org/10.1016/B978-0-08-097086-8.92001-4

Paseleng, M. C., \& Arfiyani, R. (2015). Pengimplementasian Media Pembelajaran Berbasis Multimedia Interaktif Pada Mata Pelajaran Matematika Di Sekolah Dasar. Scholaria: Jurnal Pendidikan Dan Kebudayaan, 5(2), 131. https://doi.org/10.24246/j.scholaria.2015.v5.i2.p131-149

Ratih, W. (2017). Penggunaan Multimedia Interaktif Bermuatan Game Edukasi Untuk Meningkatkan Aktivitas Dan Hasil Belajar Siswa Sekolah Dasar. Jurnal Pendidikan: Teori, Penelitian, Dan Pengembangan, 2(8).

Saraswati, Dewi, Firosalia Kristin, I. A. (2018). Peningkatan Kemampuan Pemecahan Masalah Matematika Menggunakan Model Means Ends Analysis (MEA) Bagi Siswa Kelas 5 SD Negeri Sumogawe 02. Jurnal Pendidikan Dasar PerKhasa, 4(1).

Suhendri, H. (2011). Pengaruh Kecerdasan matematis-logis dan kemandirian belajar terhadap hasil belajar matematika. Jurnal Formatif.

Sukmadinata, N. S. (2016). Metode Penelitian Pendidikan. Bandung. Remaja Rosda Karya.

Suparman, A. (2012). Desain Intruksional Modern. Erlangga.

Wahyudi, W., \& Anugraheni, I. (2017). Strategi Pemecahan Masalah Matematika. In Satya Wacana University Press (Issue August).

https://herryps.files.wordpress.com/2010/09/strategi-pemecahan-masalah-matematika.pdf

Wardani, K. W., \& Setyadi, D. (2020). Pengembangan Media Pembelajaran Matematika Berbasis Macromedia Flash Materi Luas dan Keliling untuk Meningkatkan Motivasi Belajar Siswa. Scholaria: Jurnal Pendidikan Dan Kebudayaan, 10(1), 73-84. https://doi.org/10.24246/j.js.2020.v10.i1.p73-84

Windawati, R. (2021). Pengembangan Game Edukasi Berbasis Android untuk Meningkatkan Hasil Belajar Siswa Sekolah Dasar. Jurnal Basicedu. 